\title{
Digital inclusion as a factor of political socialization of high school students
}

\author{
E. V. Morozova ${ }^{1}$, I. V. Miroshnichenko ${ }^{1}$, L. A. Shpiro ${ }^{1}$
}

${ }^{1}$ Kuban State University, 149 Stavropol str., Krasnodar Krai, Krasnodar, 350040, Russian Federation

DOI: $10.18255 / 2412-6519-2021-4-378-391$

Research Article

Full text in Russian

The purpose of this article is to identify the main trends in the influence of digital inclusion on the process of political socialization of high school students. Unconventional political activity of schoolchildren in recent years has increased the interest of scientists in the study of political socialization of children and adolescents, as well as factors influencing this process and its results. The empirical base was made up of the materials of the author's research of high school students in Krasnodar (questionnaire survey and expert sessions), as well as materials of sociological research by other authors. The level of involvement in the political life of citizens and the constructive experience of civil and political practices in a digital society largely depends on the updated set of digital competencies of citizens. Digital inclusion has the maximum impact on the political socialization of Generation Z, whose primary socialization occurred in the digital era. The level of involvement of Krasnodar high school students in digital communication is estimated as medium and high, and the level of digital competencies as medium and low. The authors have identified such vectors of the influence of digital inclusion on the political socialization of schoolchildren as: the movement from the sequence of "five transitions" of youth to their overlap and related problems of managing multitasking of identity construction; the change in the configuration of agents of political socialization from hierarchical to hybrid and the emergence of groups of youth outside the influence of traditional agents of socialization; the increasing role of digital media personalities in the formation of political views of adolescents; the development of digital technologies for the formation of political and civic identity.

Keywords: digital society, digital inclusion, generation Z, political socialization, agents of socialization

INFORMATION ABOUT THE AUTHORS

$$
\begin{array}{r|l}
\begin{array}{r}
\text { Morozova, Elena V. } \\
\text { (correspondence author) }
\end{array} & \begin{array}{l}
\text { E-mail: morozova_e@inbox.ru } \\
\text { Doc. Sc. (Philosophy), Professor }
\end{array} \\
\text { Miroshnichenko, Inna V. } & \begin{array}{l}
\text { E-mail: rector@kubsu.ru } \\
\text { Doc. Sc. (Politics) }
\end{array} \\
\text { Shpiro, Laura A. } & \begin{array}{l}
\text { E-mail: rector@kubsu.ru } \\
\text { Assistant }
\end{array}
\end{array}
$$

Funding: RFBR and EISI, project 20-011-33041

For citation: Morozova E. V., Miroshnichenko I. V., Shpiro L. A. Digital inclusion as a factor of political socialization of high school student // Social'nye i gumanitarnye znanija. 2021. Vol. 7, No 4. P. 378-391. (in Russ.)

(C) Morozova E. V., Miroshnichenko I. V., Shpiro L. A., 2021

This is an open access article under the CC BY license (https://creativecommons.org/licenses/by/4.0/) 


\title{
Цифровая инклюзия как фактор политической социализации старшеклассников
}

\author{
Е. В. Морозова ${ }^{1}$, И. В. Мирошниченко ${ }^{1}$, Л. А. Шпиро ${ }^{1}$
}

${ }_{1}^{1}$ Кубанский государственный университет, ул. Ставропольская, 149, Краснодарский край, Краснодар, 350040, Российская Федерация

DOI: $10.18255 / 2412-6519-2021-4-378-391$

УдК 323

Научная статья

Полный текст на русском языке

Целью данной статьи является выявление основных трендов влияния цифровой инклюзии на процесс политической социализации старшеклассников. Неконвенциональная политическая активность школьников в последние годы усилила интерес ученых к исследованию политической социализации детей и подростков, а также факторов, влияющих на данный процесс и его результаты. Эмпирическую базу составили материалы авторского исследования старшеклассников г. Краснодара (анкетный опрос и экспертные сессии), а также материалы социологических исследований других авторов. Уровень включенности в политическую жизнь граждан и конструктивный опыт гражданских и политических практик в цифровом обществе в значительной степени зависит от актуализированного набора цифровых компетенций граждан. Максимальное влияние цифровая инклюзия оказывает на политическую социализацию поколения Z, чья первичная социализация пришлась на цифровую эпоху. Уровень вовлеченности краснодарских старшеклассников в цифровую коммуникацию оценивается как средний и высокий, а уровень цифровых компетенций как средний и низкий. Авторы определили такие векторы влияния цифровой инклюзии на политическую социализацию школьников, как: движение от последовательности «пяти переходов» молодежи к их наложению и связанные с этим проблемы управления многозадачностью конструирования идентичностей; изменение конфигурации агентов политической социализации от иерархической к гибридной и появление групп молодежи, находящихся вне пределов влияния традиционных агентов социализации; возрастание роли цифровых медиаперсон в формировании политических взглядов подростков; развитие цифровых технологий формирования политической и гражданской идентичности.

Ключевые слова: цифровое общество, цифровая инклюзия, поколение Z, политическая социализация, агенты социализации

ИНФОРМАЦИЯ ОБ АВТОРАХ

Морозова, Елена Васильевна E-mail: morozova_e@inbox.ru

(автор для корреспонденции)

Доктор философских наук, профессор кафедры

государственной политики и государственного управления

Мирошниченко, Инна Валерьевна

E-mail: rector@kubsu.ru

Доктор политических наук, заведующий кафедрой

государственной политики и государственного управления

Шпиро, Лаура Артуровна $\mid$ E-mail: rector@kubsu.ru

Ассистент кафедры государственной политики и

государственного управления

Финансирование: РФФИ и ЭИСИ, проект № 20-011-33041 «Жизненные ценности и гражданская идентичность старшеклассников».

Для цитирования: Морозова Е. В., Мирошниченко И. В., Шпиро Л. А. Цифровая инклюзия как фактор политической социализации старшеклассников // Социальные и гуманитарные знания. 2021 . Том 7, № 4. С. 378-391.

(C) Морозова Е. В., Мирошниченко И. В., Шпиро Л. А., 2021

Статья открытого доступа под лицензией СС BY (https://creativecommons.org/licenses/by/4.0/) 


\section{Введение}

В современной социально-гуманитарной науке сложились системные представления о принципиально новом цивилизационном этапе развития общества, в котором все процессы и свойства приобретают нелинейный, сетевой характер. Источником таких изменений являются информационно-коммуникативные технологии, которые влияют на морфологию социального пространства [1], представленную сетевыми структурами, ресурсами и сообществами, на характер коммуникации в сетевом ландшафте нового социального пространства и его социокультурные основания (ценностные матрицы сетевого общества, механизмы формирования идентичностей, характер социализации, поведенческие практики индивидуальных, групповых и коллективных акторов в различных сферах жизни). Стремительная трансформация общества под воздействием цифровизации и сетевизации [2] формирует принципиально новое генеративное пространство, ускоряет рост разнообразия социальной организации, одновременно увеличивая ее чувствительность к изменениям [3].

Сетевые структуры и цифровой контент способствуют формированию групповых и коллективных представлений об общественно значимых для конкретных пользователей, сообществ, региона и страны в целом проблемах, оцениванию их значимости, определению императивов социальной деятельности граждан, формированию основания (в том числе и ценностного порядка) для солидарных действий граждан (гражданских практик) в определенной сфере. Уровень политических ориентаций отражает представления участников индивидуальных пользователей и сетевых сообществ о политической жизни и их оценку политической действительности, а также готовность участников к различным формам политических действий, как в цифровом, так и в реальном пространстве ${ }^{1}$.

Как полагают В.В. Лапкин и И.С. Семененко, «в этой новой пространственно-временной реальности формируются принципиально иные, незнакомые предшествующим эпохам механизмы социализации, иные, обезличенные методы социального контроля и дисциплинирования» [6, с. 66].

Механизмом, обеспечивающим подключение человека к новой социальной системе, его адаптацию к сетевым изменениям через обучение онлайн-жизни и формирование способностей и мотивации к различным видам деятельности в цифровом пространстве, является процесс цифровой социализации. По мнению Г.У. Солдатовой, цифровая социализация определяется как процесс освоения индивидом социального опыта посредством цифровых технологий, реализации полученных знаний, умений в офлайн/онлайн-среде, в ходе которых конструируется цифровая личность [7].

Успешность цифровой социализации в индивидуальном, групповом или коллективном срезе может определяться уровнем цифровой инклюзии. Термин «цифровая инклюзия» доминирует в зарубежном научном дискурсе и характеризует степень включенности конкретных социальных групп в технологическую

\footnotetext{
${ }^{1}$ Авторы исследовали изменение субъективного пространства политики в сетевом обществе и обобщили результаты в ряде публикаций [4; 5].
} 
инфраструктуру, обеспечивающую доступ к Интернету; освоение цифровых компетенций гражданами и личную мотивацию пользователей к обретению цифровых компетенций (различия в навыках онлайн-пользователей); дифференциацию эффективности и результативности использования цифровых технологий для различных целей граждан (приобретаемые выгоды и результаты, получаемые пользователями в профессиональной, социальной, экономической, культурной и политической сферах деятельности) [8].

В широком смысле цифровая инклюзия представляет собой социальную инклюзию в цифровом обществе, которая обеспечивает преодоление неравенства и цифровой изоляции граждан. Таким образом, успешная цифровая социализация завершается цифровой инклюзией, а последняя является важным фактором всех видов социализации, в том числе политической, в цифровом обществе.

\section{Методология и методика исследования}

Существует ряд подходов к определению понятия «поколение», но значительное влияние среди исследователей получила теория поколений, предложенная американскими учеными Н. Хоувом и У. Штраусом [9], которая соотносит границы поколений с процессом развития информационных технологий. В возрастные рамки современной молодежи входят представители двух поколений по типологии Хоува и Штрауса. Поколение Ү, или поколение миллениалов (18-35 лет), чья первичная социализация пришлась уже на постсоветскую эпоху, и поколение Z (14-18 лет) - первое поколение, сформировавшееся в цифровую эпоху, родившееся с «гаджетами в руках». Интернет для них - естественная среда, а умение работать с цифровыми технологиями - повседневная практика. Специалисты собирательно [10, с.14] называют их цифровым поколением, полагая, что представители этого поколения составляют более 40 процентов населения современной России.

В. В. Радаев предлагает свою хронологию смены поколений в современной России, автор полагает, что в 2000-е годы российское общество пережило перелом, связанный со сменой поколений, который можно охарактеризовать как вторую волну фундаментальных социальных изменений, являющихся в значительной мере наследием постсоветских политических и экономических реформ 1980 1990-х годов. «Понадобился определенный временной лаг, чтобы более молодые поколения, вошедшие в новую жизнь без старого багажа, повзрослели и, освоив новые цифровые и сетевые технологии, начали деятельно воспроизводить новые практики, делая социальные сдвиги необратимыми» [11, с.30].

Важным для данного исследования представляется концепция «пяти переходов» развития молодого поколения, предложенная И. Фроймин [12], позволившая оценить специфику переходов у представителей цифрового поколения.

В данной статье представлена интерпретация материалов эмпирического исследования, проведенного в первом полугодии 2020-2021 учебного года. Методами исследования выступили анкетный опрос и экспертные сессии. Выборка составила 264 старшеклассника (45\% мальчиков и 55\% девочек) четырёх краснодарских школ 
разных типов (гуманитарная гимназия № 36, казачья школа № 8, физико-математический лицей № 48, и средняя общеобразовательная школа № 71). Только 46\% старшеклассников выросли в семьях коренных краснодарцев, остальные приехали с родителями из разных регионов страны и районов края (по трети приезжих прибыли из регионов Сибири и Дальнего Востока, и муниципалитетов Краснодарского края, $15 \%$ - из регионов Юга России и Северного Кавказа). Один из блоков вопросов связан с включенностью старшеклассников в процессы цифровизации. Данные обрабатывались с помощью программы Statistica 6.0. Ответы на открытые вопросы анализировались с помощью качественного контент-анализа. Для верификации данных, полученных в результате анкетирования, были проведены четыре экспертных сессии (с руководителями и сотрудниками государственных органов по работе с молодежью; с директорами школ; с преподавателями истории и обществознания; с представителями школьного самоуправления и молодежных организаций).

Авторы использовали данные исследования «Российское поколение Z», проведенного российскими социологами и Фондом Фридриха Эберта по методике "FES Youth Studies" [13], а также эмпирические данные, полученные в ходе многолетних исследований цифровой компетентности молодежи Г.У. Солдатовой [7; 10], данные «Института общественного мнения» и «Медиалогии» о популярности политических видеоблогеров.

\section{Цифровая инклюзия и успешность социализации}

Цифровая инклюзия предполагает не только обеспечение доступа к новым технологиям, акцентуацию на технологических навыках, но и расширение социально-экономических прав, возможностей, социальное участие, умение продуцировать смыслы в цифровой среде [14, р. 635].

Цифровая инклюзия в современных условиях изменяет процесс, а также результаты политической социализации как неотделимой части социализации в целом, «представляющим человеку социальную адаптацию, интериоризацию и интеграцию» [15, с.89]. В традиционных подходах к политической социализации, данный процесс рассматривается как интериоризация человеком социальных ценностей, освоение политических ролей, формирование гражданских качеств и политических навыков, а также приобретение политического опыта. При этом осуществление процесса политической социализации, по мнению A.В. Мельникова, может осуществляться двумя путями: «передачей юным поколениям устоявшихся образцов политического сознания и поведения ... и приобретением новых ранее неизвестных политических знаний, а также усвоением отличного от прежнего политического опыта» [16, с.202]. Вторая траектория политической социализации непосредственно связана с усилением роли социальных медиа и сетевых структур как агентов политической социализации, с формированием нового типа политической культуры, гражданских и политических практик.

В условиях цифровизации онлайн-пространство становится продолжением физического пространства, в котором одновременно сосуществует множество культурных матриц. «Подростки воспринимают Интернет не как набор технологий, а как среду обитания, это полноценная часть их повседневной жизни, 
они давно живут на два мира: реальный и цифровой» $[10$, c.18]. Здесь изменения происходят в 3-4 раза интенсивнее, чем в любой другой сфере, что также влияет на скорость и пересечения «пяти переходов». Это приводит к совершенно новой социальной ситуации развития и, предполагаем, к аномии нового типа, связанной не только со сломом прежних социальных отношений, но и с ситуацией одномоментного нахождения в разных социальных пространствах, с разными ценностными приоритетами. Как показало исследование жизненных ценностей краснодарских старшеклассников ${ }^{1}$, большинство из них формулирует свои ценности-цели в инструментальном ключе, апеллируя к понятию цели («Упал, вставай, иди!», «Не отступать, а напролом», «Нет ничего невозможного», «Не унывать и никого не бояться»), но не фиксируя ценностного наполнения этой цели. Это совпадает с выводом, к которому пришли исследователи компетентностного выбора молодежи в условиях цифровизации: «В среде российской молодежи явно очерчена стратегия прагматизма и максимальной эффективности. Об этом свидетельствует максимальное число взаимосвязей с анализируемыми параметрами такой надпрофессиональной компетенции, как «Умение анализировать ситуацию и вырабатывать эффективные решения» [17, с.99]. Мы полагаем, что этот специфический ценностный вакуум может сделать старшеклассников (а многие уже в сентябре 2021 года стали избирателями) относительно легкой добычей популистских политических сил.

Важно, что уровень включенности в политическую жизнь граждан и конструктивный опыт гражданских и политических практик зависит от актуализированного набора цифровых компетенций граждан.

Выдвинутая М. Пренски теория «цифровых аборигенов» и «цифровых мигрантов» [18] в последнее время подвергается обоснованной критике. Г. У. Солдатова приводит результат исследований А. Кутрополоса [10, с.71], который пришел к выводу, что «цифровые аборигены» - это узкая прослойка нового поколения, это пассивные пользователи, которые обладают только базовыми пользовательскими навыками, испытывают трудности при столкновении с новыми задачами и не стремятся к интеграции неформального персонального интернет-пространства с классным или школьным. Об искусственности деления пользователей на аборигенов и мигрантов написал, исходя из своей практики, Марк Скотт, учитель информатики и администраторов сети в одной из британских школ. Опубликованная в его блоге статья «Дети не умеют пользоваться компьютерами. И вот почему это должно нас беспокоить» получила широкую известность $[10$, с. 71$]$. Сегодня остро стоит проблема повышения уровня цифрового компетентности поколения Z, формирования у них новых социальных практик и компетенций, позволяющих использовать возможности сети для саморазвития и самореализации, а также умения нейтрализовать риски и угрозы. Чем выше уровень цифровой инклюзии, тем чаще дети и подростки сталкиваются с интернет-рисками [19, с.92].

\footnotetext{
1 Школьникам предложили сформулировать свой жизненный девиз, ответы были классифицированы на 4 группы: альтруистические, эгоистические, инструментальные и неопределенные.
} 
Цифровую инклюзию подростков можно выразить некоторыми количественными характеристиками. По данным исследования «Российское поколение Z», среди российской молодежи очевиден цифровой поворот (сдвиг). 95\% имеют доступ к интернету, 84\% получают информацию о политике через интернет, 50 \% используют информацию из телевидения, но только как дополняющую сетевую $[13$, с. 6]. Результаты исследований, проводимых в Европе и США, показывают, что до 80 \% информации, получаемой детьми к 11-летнему возрасту, воспринимается ими из электронных источников вне взаимодействия со взрослыми в реальной жизни и стен школьного класса. [10, с.62]. По данным Г. У. Солдатовой, за семь лет доля школьников, ежедневно проводящих в среднем более 5 часов в Сети, выросла почти в семь раз. В 2009 году таких детей было 8\%, в 2016 - 52 \%. Около 90 процентов подростков не только ежедневно пользуются интернетом, но и отдают ему в среднем 3 часа в сутки. Автором выделено три уровня интенсивности: низкий - 1 час в день- $10 \%$ опрошенных; средний 3 часа в день - 76 \%; высокий - 8 часов и более - $14 \%$ [10, с.15-16].

По результатам проведенного нами эмпирического исследования выявлено, что все участвовавшие в опросе краснодарские школьники ежедневно заходят в сеть, причем 51,1\% опрошенных проводят во всемирной паутине 3 и более часа, а 17,8\% проводят в Интернете всё свободное время. Таким образом, старшеклассники регионального центра демонстрируют тот же уровень интенсивности пользования интернетом, который был выявлен в общероссийском опросе: $69 \%$ из них находятся на среднем и высоком уровне интенсивности пользования Сетью. Что касается оснащенности цифровыми устройствами для выхода в сеть, то среди опрошенных нами краснодарских старшеклассников только у 18,9\% есть персональный компьютер, а у 23,5\% опрошенных - ноутбук. Большинство респондентов $(65,1 \%)$ пользуются смартфонами или планшетами 1 . В то же время уровень владения цифровыми технологиями, позволяющими расширять свои социальные возможности, увеличивать человеческий капитал, можно охарактеризовать как средний и низкий. Доминирующими видами деятельности в Интернете у старшеклассников являются поиск полезной информации $(88,6 \%)$, общение в мессенджерах $(88,3 \%)$ (самые распространенные из которых - «WhatsApp» и «Telegram»), использование в развлекательных целях (игры, просмотр кино и сериалов) $(86,4 \%)$. Популярными также являются покупки товаров и услуг через Интернет $(82,2 \%)$, межличностные коммуникации (звонки и обмен мгновенными сообщениями) (78\%), пользование социальными сетями $(77,3 \%)$, самыми популярными среди которых являются «ВКонтакте» (53,8\% опрошенных), «Instagram» (36,4\% опрошенных), «Twitter» (17,8\% опрошенных). Дефицит умений и навыков особенно рельефно проявился в условиях перехода на онлайн обучение в период эпидемии коронавирусной инфекции.

\footnotetext{
${ }^{1}$ Отметим, что анализ инфраструктурной обеспеченности школ, проведенный Министерства просвещения РФ совместно с Министерством цифрового развития, связи и массовых коммуникаций РФ показал, что соответствующими возможностями в домашних условиях (наличие специально оборудованного учебного места, персональный компьютер (ноутбук) с доступом к сети Интернет) обладают не более $25 \%$ обучающихся в школах. А методические рекомендации Министерства просвещения РФ по организации дистанционного обучения запрещают использование смартфонов при онлайн-обучении.
} 
В большинстве школ формат работы во время онлайн-уроков сводился к типичному выполнению заданий и дальнейшей пересылке их учителю: «Саму работу выполняли на бумаге, то есть переписывали, делали фото и отправляли преподавателю».

Полученные Г.У. Солдатовой результаты указывают на то, что для российских подростков и их родителей в целом характерно необоснованно оптимистическое и упрощенное представление об Интернете, завышенная оценка собственной цифровой компетентности, довольно низкая мотивация к ее повышению [10, с.345-346]. Каждый шестой из опрошенных нами краснодарских подростков при ответе на вопрос об уровне владения цифровыми технологиями выбрал ответ: «я уверен, что мои знания в области цифровых техноло-

гий развиты очень хорошо и не требуют совершенствования», а 45 \% респондентов полагают, что у них «редко находится время для совершенствования своих навыков применения цифровых технологий», лишь треть опрошенных используют различные ресурсы и программы, чтобы улучшить свои цифровые навыки.

\section{Векторы влияния цифровой инклюзии на политическую социализацию старшеклассников}

Наложение «пяти переходов» развития молодого поколения. Согласно концепции «пяти переходов» развития молодого поколения[12], в жизни каждого представителя молодого поколения существует пять ключевых моментов, которые влияют на его дальнейшую жизнь - это «продолжение учебы», «начало трудовой деятельности», «усвоение навыков здоровой жизни», «создание семьи», «осуществление гражданской позиции». Качество и успешность данных переходов способствует формированию основополагающего человеческого капитала, т.е. возможности стать эффективными специалистами в профессии, главами семей, гражданами, лидерами общества и т.д. В период цифровой трансформации общества «переходы», осуществляемые молодым поколением в прежние времена преимущественно последовательно (в редком случае происходило наложение нескольких «переходов»), стали накладываться друг на друга. Высокий уровень развития цифровых компетенций, их когнитивный (умение решать проблемы, критическое мышление), социально-поведенческий (навыки межличностного общения, готовность к сотрудничеству и умение сопереживать, способность к адаптации) эффекты [20,с. 4] позволяют молодежи успешно выполнять разные роли: учиться в школе или вузе, работать по совместительству или открыть собственное предпринимательское дело, обзавестись семьей и осуществлять добровольческую деятельность, быть избранным в органы местного или молодежного самоуправления. Цифровая инклюзия молодежи не только помогает им приобретать, совершенствовать и использовать свои умения и навыки во всех сферах жизни, но обеспечивает успешность их переходов в условиях их наложения и сжатия. Социальные сети открывают новые возможности для самоидентификации и формирования новых идентичностей, приобретения новых контактов, друзей, партнеров, обретения и позиционирования собственных 
хобби и продвижения собственного дела, демонстрации гражданской и политической позиции, создания на их основе новых солидарностей или интеграция в уже существующие гражданские/политические сообщества). Цифровая среда становится пространством инвестирования в человеческий капитал молодежи, а цифровая инклюзия-механизмом инвестирования, обеспечивающим успешность человека в реализации своих стратегий в различных сферах жизни - экономической, культурной, социальной, политической). С одной стороны, оперативное и разнообразное потребление источников информации через Интернетсреду открывает перед молодежью весь спектр потенциальных возможностей для их реализации, с другой - недостаточный уровень когнитивных навыков, основанных на цифровой грамотности, может вести к непродуманным, спонтанным решениям - будь то решения из сферы финансов или поддержка новой политической партии.

Изменение структуры агентов социализации. В научном дискурсе присутствуют утверждения о том, что «на смену иерархической структуре, где ключевыми агентами социализации выступают институт семьи, школы, традиционные СМИ, приходит сетевая модель с присущими ей нелинейными и неиерархическими процессами» [15, с.88]. Не отрицая сам процесс деиерархизации агентов политической социализации, выразим сомнение в том, что сетевая модель уже сложилась или даже приходит на смену традиционной. Полагаем, что конфигурация агентов социализации носит гибридный характер, а сам тип конфигурации не является единым для России с ее региональным разнообразием. Краснодарские школьники высоко оценили роль Интернета в формировании гражданских качеств молодежи - 7,9 по 10-балльной шкале, но роль семьи оценена выше- 8,5; друзей практически так же - 7,7; школы - 6,5; художественной культуры - 5,4; СМИ - 5,3; общественных организаций - 4,4; политических партий - 3,9. Вероятно, в других регионах конфигурация будет складываться иначе, и совсем по-другому она будет выглядеть в Москве.

Особенности конфигурации гибридной модели будут определять и образ жизни, и социальные практики различных групп молодежи. К примеру, мы наблюдаем рост слоя молодежи, который называют NEET-поколением ("NotinEmployment, EducationorTraining"). Это экономически неактивная молодежь в возрасте 15-29 лет, которая не учится, не охвачена профессиональной подготовкой и пассивно потребляет имеющиеся в семье ресурсы [21, с.23]. Этот слой, а он довольно многочисленный ${ }^{1}$, погружен в основном в стихийные процессы политической социализации и находится вне пределов досягаемости ее традиционных агентов, роль Интернета и его сетевых сообществ для NEETпоколения является исключительной.

Возрастающая роль цифровых медиаперсон в политической социализации старшеклассников. В нашем исследовании старшеклассникам предложили назвать людей, которых они считают истинными гражданами России. Некоторые ответы были ожидаемы, школьники называли имена политиков федераль-

\footnotetext{
${ }^{1}$ По оценкам каждый шестой молодой человек в возрасте 20-29 лет в России не имеет работы и не учится $[21$, c. 23].
} 
ного и регионального уровня (Президент России В.В. Путин, министр иностранных дел С. Лавров, губернатор Краснодарского края В Кондратьев), известных бизнесменов (С.Н. Галицкий) и деятелей культуры (В. Захарченко). Но часть представителей поколения Z увидели образцы гражданственности в блогерах И. Варламове, Ю. Дуде, М. Каце, Е. Шульман. Вопреки стереотипным представлениям о том, что подростки интересуются в основном развлекательным контентом в Интернете, мы видим возрастающий интерес к блогам социально-политической направленности. По данным портала «Институт общественного мнения» 1 из 1258 жителей России (25\% из который молодые люди от 18 до 30 лет) 28 \% респондентов интересуются политическими блогами. Наибольшую популярность имеют именно видеоблоги, ими интересуются 77\% опрошенных. Половина опрошенных просматривает блоги ежедневно, 56 \%, доверяют информации, полученной в блогах, так как считают блогеров независимыми в своих суждениях и высказываниях.

Канал Юрий Дудя² по статистике ресурса «Медиалогия» ${ }^{3}$ входит в топ-10 каналов YouTube за 2020 год. Количество подписчиков на его канале превышает 9 млн человек. «Он ближе к нам, он разговаривает как мы, он ведет себя абсолютно нормально, он приземленный. Он обычный русский» ${ }^{4}$ «Он приглашает очень много людей, очень много экспертов, признанных и на государственном уровне. Он предоставляет разные точки зрения, поэтому ему можно доверять. Плюс, как мне кажется, у него нет интереса сказать неправду, соврать и т. д.»Он один из лучших контентмейкеров. Он создает очень качественный материал: по картинке, по наполняемости, по спецэффектам. Он подкупает своей свободой».

С блогом политолога Екатерины Шульман ${ }^{5}$ знакомы 25\% опрошенных, а степень доверия данному блогеру также высока. Это связано с профессионализмом Екатерины, ее опытом деятельности в данной сфере и уважением к ней со стороны высокопоставленных лиц. «Её уважает огромное количество людей из высших эшелонов власти. При мне к ней подошел Собянин и общался с ней, хотя она высказывает достаточно оппозиционные взгляды». «Как бы человек к ней не относился, но с её мнением надо считаться, она профессионал, она что-то в этом понимает».

Разделяем мнение Л.В. Ивановой о том, что политические блоги становятся механизмом коллективной сетевой дискуссии, создают условия для соревновательных и конкурентных мнений и взглядов на процессы управления, решения и изменения в стране[22], а для цифрового поколения они становятся важным инструментом политической социализации, позволяя формировать ценностные ориентации и модели политического поведения и избегая «эффекта

\footnotetext{
${ }^{1}$ Институт общественного мнения. «Россияне - о блогах и блогерах»: сайт. [2018].URL: https://iom.anketolog.ru/2018/06/13/rossiyane-o-blogah (дата обращения:29.02.2020).

${ }^{2}$ YouTube-канал «вДудь»: сайт. [2021].URL: https://www.youtube.com/channel/UCMCgOm8GZkHp8zJ6I7_hluA (дата обращения: 9.06.21).

${ }^{3}$ Топ-20 каналов в YouTube- 2020: сайт.[2021]. URL:https://www.mlg.ru/ratings/socmedia/youtube/8036/ (дата обращения: 19.06.21).

${ }^{4}$ Использованы фрагменты интервью, проведенные студенткой факультета управления и психологии Кубгу В.Цукановой в марте-апреле 2021 года.

${ }^{5}$ YouTube-канал «Екатерина Шульман»: сайт. [2021]. URL:

https://www.youtube.com/channel/UCL1rJOROIw9V1qFeINOZTZQ (дата обращения: 19.06.21).
} 
навязанности». Таким образом, мы наблюдаем развитие тенденции, отмеченной исследователями несколько лет назад - «в политическом процессе наряду с государством-нацией и функционирующими в поле публичной политики институтами уже прочно утвердились и продолжают утверждаться акторы разного уровня и степени субъектности (agency)» [6, c.67]. В цифровом обществе такая разноуровневая и разноплановая субъектность претендует на самодостаточность и трансформирует «неполитическое» в политическое.

Цифровые механизмы формирования политической и гражданской идентичностей.Мы наблюдаем преодоление «цифрового дуализма» (разделения цифровой и физической реальности): анонимность и связанные с ней игры с идентичностью теряют свою актуальность, реальная идентичность практически сращивается с виртуальной, превращаясь в единый цифровой профиль личности. В то же время, по данным исследования «Дети России онлайн» почти треть опрошенных детей признались, что хотя бы раз представлялись в сети другим человеком. Деиндивидуализация приводит к снижению чувства ответственности за свои действия, следствием чего может стать антиообщественное поведению в онлайне. [10,с.42-48]. Заметной тенденцией стало распространение (а в некоторых случаях преобладание) визуализированных или синтетических (таких как мем) форм политической идентификации. Л. А. Фадеева указывает и на появление такого явления как сетевой нарциссизм [23, с. 238]. Как заметил 3. Бауман, «большинство людей используют социальные медиа не для того, чтобы объединиться или расширить горизонты, а, напротив, чтобы ограничить себя комфортной зоной, где единственные звуки, которые они слышат, это эхо их собственного голоса» [24].

Происходит противоречивое переплетение позитивных и негативных эффектов влияния цифровизации на процессы формирования политической и гражданской идентичности. С одной стороны, наблюдается формирование в сетевом взаимодействии компетенций, востребованных современной реальностью - эмоционального интеллекта, коллективной креативности, адаптивности, открытости. С другой стороны, возникает опасность кластеризации людей по различным признакам, создания индивидуальных социальных рейтингов (по типу китайского эксперимента), упрощения речи и неспособности составить связный текст; «информационной булимии» и др. Нарастание негативных эффектов породило движение «цифрового детокса» - сознательного отказа от использования гаджетов и игнорирование социальных сетей на определенный срок.

Источники информации: интернет вне конкуренции. По данным исследования «Цифровое поколение России» $[13$, с.48], основные источники информации о политических событиях таковы: интернет - 84\%, телевидение - 50\%, социальные медиа -26\%, общение с друзьями - 19\%, общение с родными - $18 \%$, радио 9\%, газеты - 5\%. Очевидно, что самым значимым для них источником информации школьники называют Интернет (8,6 по 10-балльной шкале), следующую позицию разделяют личные коммуникации со сверстниками и друзьями $(7,7$ по 10 -балльной шкале), а также с учителями и родителями (7,4 по 10-балльной шкале). Что касается традиционных СМИ, то телевидение как источник инфор- 
мации для школьников является не актуальным (3 по 10-балльной шкале), выбор радио и газет (1,4 и 1 по 10-балльной шкале соответственно) занимает низшую ступень. Данные по значимости источников информации для школьников отражены на рис. 1.

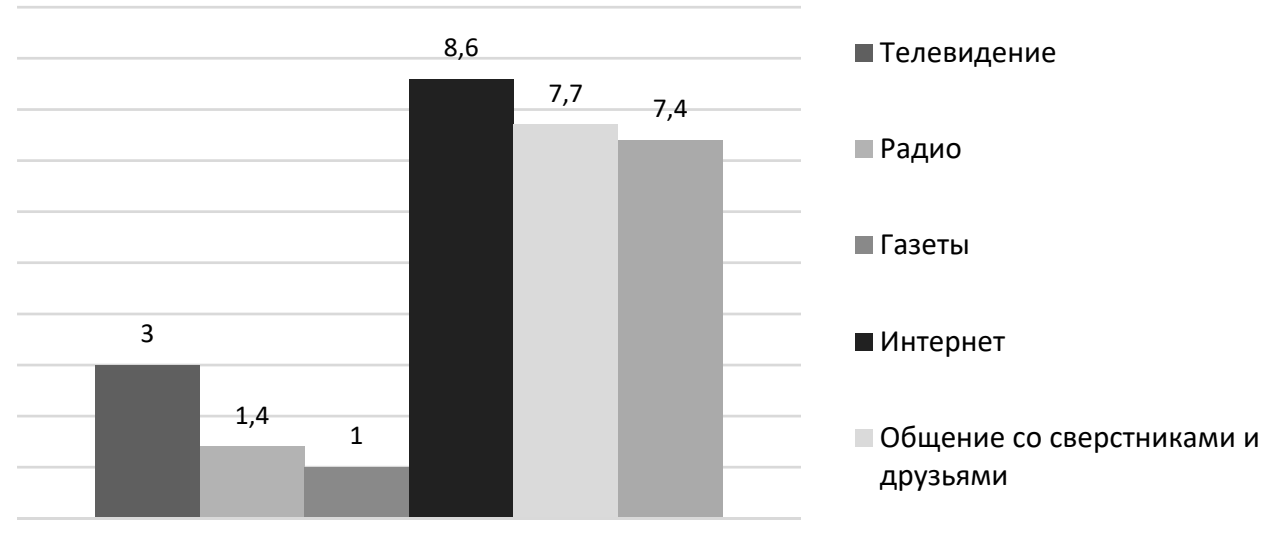

Рисунок 1. Значимость источников информации для старшеклассников г. Краснодара (10-балльная шкала, средний показатель от количества опрошенных)

Говоря об Интернете как важнейшем источнике информации отметим, что полностью доверяют информации, публикуемой в цифровом пространстве, только 1,1\% школьников, скорее доверяют - 56,1\%, скорее не доверяют - 25 \%, не доверяют вовсе $-4,5 \%$. Таким образом, безоговорочного доверия сетевой информации у старшеклассников нет, в то же время уровень доверия этой информации выше, чем той, которая получена из традиционных СМИ.

\section{Заключение}

Максимальное влияние цифровая инклюзия оказывает на политическую социализацию поколения Z, чья первичная социализация пришлась на цифровую эпоху. По результатам эмпирического исследования уровень вовлеченности краснодарских старшеклассников в цифровую коммуникацию оценивается как средний и высокий, а уровень цифровых компетенций как средний и низкий. При этом школьникам свойственны оптимистическое и упрощенное представление об Интернете, завышенная оценка собственной цифровой компетентности, довольно низкая мотивация к ее повышению Основными векторами влияния цифровой инклюзии на политическую социализацию школьников являются движение от последовательности «пяти переходов» молодежи к их наложению и связанные с этим проблемы управления многозадачностью конструирования идентичностей. По мере включения в цифровые практики происходит изменение конфигурации агентов политической социализации от иерархической к гибридной. Появляются группы молодежи, находящиеся вне пределов влияния 
традиционных агентов социализации; значительно возрастает роль цифровых медиаперсон в формировании политических взглядов подростков.

\section{Ссылки / References}

1. Кастельс М. Информационная эпоха: экономика, общество и культура / Пер. с англ. под науч. ред. О. И. Шкаратана. М.: ГУ ВШЭ, 2000. 608 с.

2. Лазар М. Г. Цифровизация общества, её последствия и контроль над населением // Проблемы деятельности учёных и научных коллективов. 2018. № 4 (34). С. 170181.

3. Асмолов Г. А., Асмолов А. Г. Интернет как генеративное пространство: историкоэволюционная перспектива // Вопросы психологии. 2019. № 4. С. 3-28.

4. Рябченко Н. А., Мирошниченко И. В., Гнедаш А. А. От «квазикритики власти» к дискурсу «соучастия и развития»: общественная повестка дня в социальных сетях Рунета (практики сетевых сообществ) // Южно-российский журнал социальных наук. 2020. Том 21, № 3. C. 20-36. DOI: 10.31429/26190567-21-3-20-36

5. Плотичкина Н. В., Морозова Е. В., Мирошниченко И. В. Цифровые технологии: политика расширения доступности и развития навыков использования в Европе и России // Мировая экономика и международные отношения. 2020. Том 64, № 4. C. 70-83. DOI: 10.20542/0131-2227-2020-64-4-70-83

6. Лапкин В. В., Семененко И. С. «Человек политический» перед вызовами «infomodernity» // Полис. Политические исследования. 2013. № 6. С. 64-81.

7. Солдатова Г.У. Цифровая социализация в культурно-исторической парадигме: изменяющийся ребенок в изменяющемся мире // Социальная психология и общество. 2018. Том 9, № 3. C. 71-80. DOI: 10.17759/ sps.2018090308

8. Van Deursen A. J. A. M., Helsper E., Eynon R., van Dijk J. A. G. M. The Compoundness and Sequentiality of Digital Inequality // International Journal of Communication. 2017. № 11.P. 452-473.

9. Howe N., Strauss W. The Next 20 Years: How Customer and Workforce Attitudes Will Evolve // Harvard Business Review. 2007. Vol. 85, № 7-8. P. 47-52.

10. Солдатова Г. У., Рассказова Е. И., Нестик Т. А. Цифровое поколение России: компетентность и безопасность. М.: Смысл, 2017. 375 с.

11. Радаев В. В. Миллениалы: Как меняется российское общество. М.: Изд. дом ВШЭ, 2019. 224 c.

12. Froumin I. D. Socio-Economic Development and the Next Generation: Five Transitions // Journal of Siberian Federal University. Humanities \& Social Sciences. 2012. № 5. P. 1534-1541.

13. Kochergina E., Gudkov L., Zorkaya N., Pipiya K., Ryseva A. Russia's 'Generation Z': Attitudes and Values, 2019/2020. Moscow: Friedrich-Ebert-Stiftung Publ., 2020. 144 p.

14. Al-Muwil A., Weerakkody V., El-haddadeh R., Dwivedi Y. Balancing Digital-By-Default with Inclusion: A Study of the Factors Influencing E-Inclusion in the UK // Information Systems Frontiers. 2019. № 21. P. 635-659. 
15. Малькевич A.A. Социальные сети как фактор политической социализации молодежи: от иерархии к сетевой модели// Вестник Московского университета. Сер. 12. Политические науки. 2019. №6. С. 88-97.

16. Мельников А. В. Эффективная модель политической социализации молодежи // Власть. 2016. Том 24, № 3. С. 201-204.

17. Бродовская Е. В., Домбровская А. Ю., Пырма Р. В., Синяков А. В., Азаров А. А. Взаимосвязь ценностного и компетентностного выбора молодежи в условиях цифровизации: результаты всероссийского исследования (2018 г.) // Ценности и смыслы. 2019. № 2 (60). C. 76-104. DOI: 10.24411/2071-6427-2019-10057

18. Prensky M. Digital Natives, Digital Immigrants // On the Horizon. 2001. Vol. 9, № 5. October.

19. Бродовская Е. В., Домбровская А. Ю., Синяков А. В. «Цифровое детство»: риски интернет-коммуникации школьников, их родителей и учителей (по материалам прикладного исследования в Ставропольском крае, 2020 г.) // Власть. 2020. № 5. C. 86-94. DOI: 10.31171/vlast.v28i5.7577

20. Всемирный банк. Доклад о мировом развитии 2019 «Изменение характера труда». Вашингтон, округ Колумбия: Всемирный банк, 2019. 152 с. DOI:10.1596/978-14648-1328-3

21. Беляева Л. А. Российская молодежь в эпоху перемен структурные изменения и новые вызовы политической социализации // Вопросы философии. 2020. № 10. C. 17-27. DOI: 10.21146/0042-8744-2020-10-17-27

22. Иванова Л. В. К вопросу о кризисе критического мышления в дискурсе политической блогосферы // Знак: проблемное поле медиаобразования. 2020. № 1 (35). С. 102-111.

23. Фадеева Л.А. Сетевая идентичность // Идентичность: Личность. Общество. Политика. Энциклопедическое издание / Под ред. И. С. Семененко. М.: Весь мир, 2017. С. 235-240.

24. De Querol R. Zygmunt Bauman: "Social Media Are a Trap" // El Pais: сайт. [2016. 25.01]. URL: https://english.elpais.com/elpais/2016/01/19/inenglish/1453208692_424660.html (дата обращения: 20.07.2021). 